Profit: Jurnal Kajian Ekonomi dan Perbankan 3 (2) 2019. P: 38-50

PROFIT : JURNAL KAJIAN EKONOMI DAN PERBANKAN https://ejournal.unuja.ac.id/index.php/profit

P-ISSN : 2685-4309 E-ISSN : 2597-9434

\author{
Abdul Majid Toyyibi \\ abdulmajidtoyyibi93@gmail.com
}

\title{
IMPLEMENTASI HAWALAH PADA PEMBIAYAAN BERMASALAH STUDI KASUS KOPERASI JASA KEUANGAN SYARIAH USAHA GABUNGAN TERPADU BMT SIDOGIRI KCP OMBEN TAHUN BUKU 2018
}

Financing is the most important part of the milestone of an Islamic financial institution, its existence must be able to avoid the problematic financing that can hamper the value of its income. So that the existence of hawalah contract becomes a new solution in minimizing problem financing. So that in this study there are two formulations of the problem namely the practice of hawalah by reviewing the MUI fatwa and the type used by BMT Sidogiri. The research method used is descriptive qualitative in which the researcher descends directly to the study site by conducting interviews and collecting primary and secondary data sources as a complement and then from there an analysis of the data is conducted

As for the results of his research that the pillars and legal requirements of the law in KJKS UGT BMT Sidogiri KCP Omben are in accordance with the pillars and conditions according to Islamic economics and the MUI DSN fatwa regarding hawalah DSN MUI fatwa which has been decided related to hawalah. The implementation of hawalah, which is between muhil and muhal alayh, comes to KJKS UGT BMT Sidogiri KCP Omben to provide information that installments that are borne by the muhil parties will be continued with the financing installments by the muhal alayhi when legally obliged to fulfill the conditions and regulations.

Keyword : hawalah, BMT, 


\section{PENDAHULUAN}

Lembaga keuangan perbankan syariah adalah sebuah lembaga intermediasi yang menegakkan aturan ekonomi islam. Kegiatan pokoknya pada dua hal yakni melakukan penghimpunan dana masyarakat dan menyalurkan dana. Bank syariah tantangan resiko terbesar berada pada penyaluran dana berupa pembiayaan. Hal resiko pembiayaan tak bisa dihindari oleh lembaga keuangan syariah, secara umum risiko-risiko yang melekat pada aktivitas fungsional bank syariah dapat diklasifikasikan kedalam 3 jenis risiko, salah satunya adalah risiko pembiayaan. Yang dimaksud risiko pembiayaan yakni risiko yang disebabkan oleh adanya kegagalan couterparty dalam memenuhi kewajibannya. Dalam bank syariah, risiko pembiayaan mencakup risiko terkait produk dan risiko terkait pembiayaan korporasi. ${ }^{1}$

Semakin tingginya tingkat pembiayaan bermasalah di sebuah lembaga keuangan perbankan syariah menjadikan alat sebagai pengangkat semangat bagi employee bank tersebut untuk menyelesaikan berbagai masalah dalam hal ini pembiayaan bermasalah.Penyebab terjadinya pembiayaan bermasalah mempunyai 2 kemungkinan kesalahan yakni dari pihak lembaga keuangan syariah (LKS) dan nasabahnya.

Kesalahan dari pihak LKS ketika melakukan analisis pembiayaan dikhawatirkan pihak analis kurang begitu teliti ataupun ada kolusi antara pihak peminjam dengan pihak analis sehingga kemungkinan besar akan ada pemalsuan data. Adapun kesalahan dari nasabah dimungkinkan karena nasabah tersebut memang tidak mampu membayarnya/bangkrut ataupun nasabah memang tidak mempunyai iktikad baik untuk membayar angsuran tersebut.

Dalam agama islam dikenal adanya lembaga pengalihan hutang atau hawalah merupakan pengalihan tangguhan hutang dari orang yang ber-utang kepada orang lain yang wajib menanggungnya. Karena itu, hawalah ini merupakan suatu persoalan yang penting, apalagi pada masa sekarang.

Baitul Maal Wat Tamwil merupakan suatu lembaga, yang terdiri dari dua istilah, yaitu baitul maal dan baitul tamwil. Baitulmaal lebih mengarah pada usaha-usaha pengumpulan dan penyaluran dana yang non-profit, Baitul tamwil sebagai usaha pengumpulan dan penyaluran dana komersial. Usaha-usaha tersebut menjadi bagian yang tidak terpisahkan dari BMT sebagai lembaga pendukung kegiatan ekonomi masyarakat kecil dengan berlandaskan islam. $^{2}$

Koperasi jasa keuangan syariah usaha gabungan terpadu BMT Sidogiri KCP Omben merupakan sebuah lembaga keuangan mikro yang tidak saja focus pada pengumpulan dan penyaluran dana masyarakat namun lembaga keuangan tersebut juga mengikuti arus yang saat-saat ini berkembang dan sering kali terjadi sebuah fenomena berupa pembiayaan bermasalah tepatnya di daerah peneliti tinggal, oleh karena nya sangat tidak dipungkiri kembali adanya lembaga keuangan tersebut menjadi penengah ketika masalah itu berkembang dengan mengalihkan hutang nya dengan prosedur yang jelas dan al-qur'an, alhadis sebagai pedoman untuk menyelesaikannya, maka dengan kejadian diatas peneliti

1 Karim Adiwarman, Bank Islam (Jakarta: PT.Raja Grafindo, 2010), hlm.260.

2 Huda Nurul, Heykal Muhammad, Lembaga Keuangan Islam (Jakarta: Kencana Prenda Media Group, 2010), hlm.363. 
menjadikan judul penelitian "Implementasi Hawalab Pada Pembiayaan Bermasalah Studi Kasus Koperasi Jasa Keuangan Syariah Usaha Gabungan Terpadu BMT Sidogiri KCP Omben Tahun Buku 2018”.

\section{TEORI}

\section{KAJIAN HAWALAH}

Dalam keilmuan muamalah pengalihan hutang lebih dikenal dengan Al-hawalah. Secara harfiah artinya pengalihan, pemindahan, perubahan warna kulit atau memikul sesuatu diatas pundak. Objek yang dialihkan dapat berupa utang atau piutang. Jenis akad ini pada dasarnya adalah akad tabarru' yang bertujuan untuk saling menolong untuk menggapai ridho Allah.

Jika yang dialihkan utang maka akad hawalah merupakan akad pengalihan hutang dari satu pihak yang berutang kepada pihak lain yang wajib menanggung membayar utangnya. Transaksi seperti ini dapat terjadi dengan adanya saling mempercayai antara pihak yang bertransaksi. $^{3}$

Pengertian hawalah yang ditetapkan oleh UU No.21 Tahun 2008 secara substansial sama dengan yang difatwakan oleh dewan syariah nasional (DSN) majelis ulama' indonesia (MUI) dengan sedikit perbedaan redaksional bahasa. UU menghilangkan kata "satu" sebelum kata "pihak" dari definisi hawalah yang difatwakan dewan syariah nasional (DSN) majelis ulama' indonesia (MUI), sehingga pengertian hawalah versi UU ialah, "akad pengalihan hutang dari pihak yang berutang kepada pihak lain yang wajib menanggung atau membayar". 4

1. Landasan Syariah

Pelaksanaan al-hiwalah dibenarkan dalam islam, sebagaimana Sabda Rasulullah SAW :

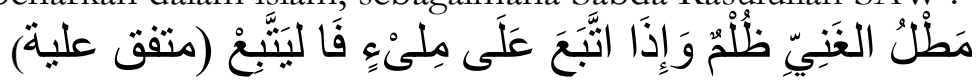

Artinya : memperlambat pembayaran hutang yang dilakukan oleh orang mampu merupakan perbuatan zalim. Jika salah seorang kamu dialihkan kepada orang yang mudah membayar hutang, maka hendaklah ia beralih (diterima pengalihan tersebut). (Muttafaqun 'alaih).

Sabda Rasulullah SAW :

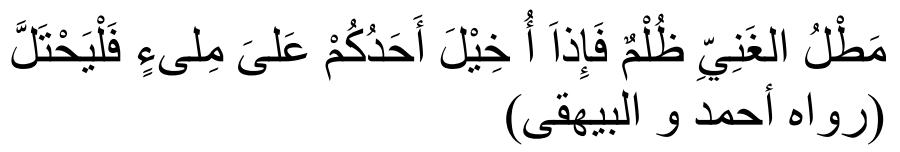

Artinya : Orang yang mampu membayar hutang haram atasnya melalaikan hutangnya. Apabila salah seorang diantara kamu memindahkan hutangnya kepada orang lain, hendak lah diterima pemindahan itu, asal yang lain itu mampu membayarnya. (HR.Ahmad dan Baihaqi).

Para ulama sepakat (ijma) membolehkan hawalah. Hawalah pada utang yang tidak berbentuk barang/benda karena bawalah adalah perpindahan utang. Oleh sebab itu, harus pada uang atau kewajiban finansial. ${ }^{5}$

7 Nurhayanti Sri, Akuntansi Syariah Di Indonesia (Jakarta: Salemba Empat, 2011), hlm.260.

8 Atang abd hakim, Fiqh Perbankan Syariah (Bandung: PT Refika Aditama, 2011), hlm.283.

9 Muhammad syafi'i antonio, Bank Syariah (Jakarta: gema insani, 2001), hlm.127. 
1. Rukun, syarat dan manfaaat hawalah

Allah mensyariatkan akad hawalah karena telah menjadi kebutuhan manusia. Melalui akad hawalah, seseorang dapat mengalihkan hak piutang dari pihak yang mengalami kesulitan financial kepada pihak lain yang berkecukupan. Adapun rukun dan syarat yang harus dipenuhi untuk mencapai tujuan hawalab adalah:

1) Adanya para pihak yang mengadakan akad hawalah. Para pihak yang terlibat dalam akad hawalah umumnya terdiri dari, yaitu: (a) pihak berutang dan berpiutang yang akan mengalihkan utangnya (mubil), (b) pihak yang memberikan utang (mubal labu) dan (c) pihak lain yang menerima pengalihan utang untuk dilunasinya (mubal 'alaib), namun agar keabsahan akad hawalah dapat terwujud, maka masing-masing pihak harus memenuhi syarat sebagai subjek hukum.

2) Sesuatu yang menjadi objek akad hiwalah (mubalul bib) adalah yang bersifat financial. Hiwalah tidak diperbolehkan berlaku terhadap utang yang bersifat barang. Karena itu agar dapat dihiwalahkan, utang harus memenuhi syarat-syarat sebagai berikut :

a) Utang tersebut merupakan akibat hukum dari suatu akad yang bersifat pasti (luzum). Karena itu tidak sah hukumnya mengalihkan hutang yang timbul dari suatu akad yang masih berlaku hak khiyar.

b) Jika pengalihan hutang berbentuk hiwalah muqayyadah maka jumlah secara kuantitas/kualitas utang yang dialihkan harus sama. Karena apabila jumlahnya berbeda, hukumnya menjadi tidak sah, kecuali sisa biwalah tersebut dikembalikan kepada para pihak untuk menyelesaikan sendiri menurut hak dan kewajibannya, sedangkan apabila pengalihan berbentuk biwalah mutlaqah, maka jumlah utang yang dialihkan tidak mesti sama, tergantung kesediaan dan kemampuan pihak yang akan menerima pengalihan utang tersebut (mubal 'alaib).

c) Pada prinsipnya pembayaran utang bisa dilakukan secara tunai (naqdan) atau tangguh (muajjal), tergantung kesepakatan para pihak. Namun dalam hal ini diisyaratkan, bahwa pihak yang menerima pengalihan hutang (mubal 'alaib) adalah orang yang dijamin memiliki kemampuan untuk melunasi utang tersebut.

3) Pernyataan ijab qabul (shigat al-'aqd) harus dinyatakan oleh para pihak untuk menunjukkan kehendak mereka mengadakan pengalihan hutang. Dalam akad hiwalah, pernyataan ijab qabul bisa datang dari pihak yang ber-utang (mubil) maupun pihak yang menerima pengalihan hutang (mubal 'alaib). Pernyataan ijab yang datang dari pihak yang berutang (mubil) misalnya: "Saya hiwalabkan utang ku agar menjadi kewajibanmu untuk membayarnya" sedangkan pernyataan qabul dari pihak yang menerima hiwalah (mubal 'alaib) misalnya: "Saya terima biwalah engkau untul melunasi utang".

Namun yang perlu dipahami, bahwa pernyataan ijab qabul harus diketahui oleh pihak yang mengutangi (mubal labu). Ketentuan ini didasarkan pada pertimbangan, bahwa Rasulullah memerintahkan kepada pihak yang mengutangi (mubal lahu) untuk mengetahui dan menerima hiwalah, terutama jika ada orang yang mengalihkan pembayaran utangnya kepada yang mampu. Nabi bersabda. ${ }^{6}$

10 Burhanuddin, Hukum Kontrak Syariah (Yogyakarta: BPFE Yogyakarta, 2009), hlm.140. 


\section{إذا أحيل احد كم على ملىئ فليتّبع}

Artinya : Dan jika salah seorang diantara kamu dihiwalahkan kepada orang yang kaya, maka terimalah.

Akad hawalah dapat memberikan beberapa manfaat dan keuntungan, di antaranya:

1. Memungkinkan penyelesaian hutang piutang dengan cepat.

2. Tersedianya talangan dana untuk hibah bagi yang membutuhkan.

3. Dapat menjadi salah satu fee-based income/sumber pendapatan nonpembiayaan bagi bank syariah.

\section{Macam-Macam Hiwalah}

Mazhab Hanafi membagi hawalah dalam beberapa bagian. Ditinjau dari segi obyek, maka hawalah dapat dibagi menjadi dua :

1) Apabila yang dipindahkan itu merupakan hak menuntut hutang, maka pemindahan itu disebut hiwalah al-haqq (بحو آلَّة الحَقّقب= Pemindahan hak).

2) Apabila yang dipindahkan itu kewajiban untuk membayar hutang, maka pemindahan itu disebut hiwalah al-dain (جو آلَةُالدَّيْن ب) Pemindahan hutang

Ditinjau dari sisi lain, hawalab terbagi dua pula :

1) Pemindahan sebagai ganti dari pembayaran hutang pihak pertama kepada pihak

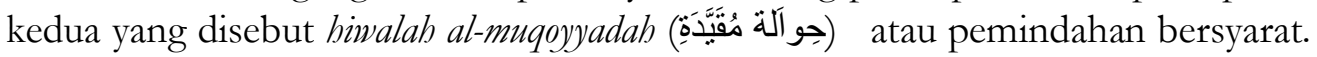
Sebagai contoh : A berpiutang kepada B sebesar Rp.5.000.000,- sedangkan B juga berpiutang kepada C sebesar Rp.5.000.000,-. B kemudian memindahkan atau mengalihkan haknya untuk menuntut piutangnya yang berada pada C, kepada A sebagai pengganti dari pembayaran hutang B kepada A. Dengan demikian hiwalah al-muqayyadah, pada satu sisi merupakan hiwalah al-haqq, karena mengalihkan hak menuntut piutangnya dari C ke A. Sedangkan pada sisi lain, sekaligus merupakan biwalah al-dain, karena B mengalihkan kepaa A, menjadi kewajiban $C$ kepada A.

2) Pemindahan hutang yang tidak ditegaskan sebagai ganti dari pembayaran hutang pihak pertama kepada pihak kedua yang disebut biwalah al-mutlaqob (حِوَالَة مُطْلَقَقَ) atau pemindahan mutlak. Sebagai contoh : A berhutang kepada B sebesar Rp.5.000.000,-. A mengalihkan hutangnya kepada $C$ sehingga $C$ berkewajiban membayar hutang A kepada B tanpa menyebutkan, bahwa pemindahan hutang tersebut sebagai ganti rugi dari pembaran hutang $C$ kepada A. Dengan demikian, biwalah al-mutlaqah hanya mengandung biwalah al-dain saja, karena yang dipindahkan, hanya hutang A kepada B menjadi hutang C kepada B. ${ }^{8}$

\section{KAJIAN PEMBIAYAAN BERMASALAH}

Dalam melakukan kegiatannya lembaga keuangan syariah menggunakan prinsip kehati-hatian oleh karenanya bank syariah sebagai intermediasi selalu berhati-hati ketika

11 Dumairi nor dkk, Ekonomi Syariah (Pasuruan: Pustaka Sidogiri, 2008), hlm.129.

12 M Ali Hasan, Berbagai Macam Transaksi dalam Islam (Jakarta: PT.Raja Grafindo, 2004), hlm.221. 
melaksanakan kegiatannya yakni penghimpunan dana dan penyaluran dana berupa pembiayaan. Realisasi pembiayaan suatu bank pasti memiliki nasabah yang bermasalah karena hal itulah yang sering terjadi dilapangan.

1. Pengertian

Pembiayaan bermasalah adalah pembiayaan yang kolektibilitasnya tergolong : 1). Dalam perhatian khusus 2). Kurang lancar 3). Diragukan 4). Macet. ${ }^{9}$

2. Macam-macam pembiayaan

Dalam melaksanakan jenis pembiayaan, dapat dilihat dari tujuan, jangka waktu, jaminan, orangnya (yang menerima dan memberi pembiayaan), dan tempat kediamaannya.

1) Jenis pembiayaan dilihat dari tujuan

a. Pembiayaan investasi

Pembiayaan investasi ini ditujukan untuk pendirian perusahaan atau proyek baru maupun proyek pengembangan, modernisasi mesin dan peralatan, pembelian alat angkutan yang digunakan untuk kelancaran usaha, serta perluasan usaha.

b. Pembiayaan modal kerja

Pembiayaan modal kerja ini diberikan dalam jangka pendek yaitu selama-lamanya satu tahun. Kebutuhan yang dapat dibiayai dengan menggunakan pembiayaan modal kerja antara kebutuhan bahan baku, biaya upah, pembelian barang-barang dagangan dan kebutuhan dana lain yang sifatnya hanya digunakan selama satu tahun, serta kebutuhan dana yang diperlukan untuk menutup piutang perusahaan.

2) Jenis pembiayaan dilihat dari jangka waktu

a. Pembiayaan jangka pendek

Adalah suatu bentuk pembiayaan yang berjangka waktu maksimal satu tahun.

b. Pembiayaan jangka waktu menengah

Ialah suatu bentuk pembiayaan yang berjangka waktu 1-3 tahun.

c. Pembiayaan jangka panjang

Pembiayaan yang jangka waktunya lebih dari tiga tahun. ${ }^{10}$

3) Jenis pembiayaan dilihat menurut lembaga yang menerima pembiayaan

4) Jenis pembiayaan menurut sektor ekonomi

a. Sektor pertanian, perburuhan dan sarana pertanian

b. Sektor pertambangan

c. Sektor perindustrian

d. Sektor listrik gas dan air

e. Sektor konstruksi

f. Sektor perdagangan, restoran, dan hotel

g. Sektor pengangkutan, pergudagangan dan komunikasi

h. Sektor jasa-jasa dunia usaha

i. Sektor jasa-jasa sosial

j. Sektor lain-lain

13 Ahmad Ifham Solihin, Ekonomi Syariah (Jakarta: PT. Gramedia Pustaka Utama, 2010), hlm.599. 14 Ismail, Perbankan Syariah (Jakarta: Kencana, 2011), hlm.111. 
5) Jenis pembiayaan menurut sifat

Adalah berhubungan dengan perkembangan baki debet sejak pembiayaan ditarik/digunakan sampai dengan pembiayaan dilunasi.

6) Jenis pembiayaan yang disalurkan menurut bentuk

a. Cas loan / tunai

b. Non cas loan / non tunai

7) Jenis pembiayaan menurut sumber dana

a. Pembiayaan dengan dana bank sendiri

b. Pembiayaan dengan dana bersama-sama

c. Pembiayaan dengan dana dari luar negeri

8) Jenis pembiayaan wewenang pemutusan

Dilihat dari sudut wewenang pemutusannya, maka pembiayaan dibedakan atas wewenang kantor wilayah, wewenang cabang, dan wewenang kantor pusat (kepala divisi, direksi).

9) Jenis pembiayaan menurut sifat fasilitas

\section{a. Commited facility}

Adalah suatu fasilitas yang secara yuridis bank berkewajiban untuk memenuhinya sesuai dengan yang diperjanjikan.

b. Uncommited facility

Adalah suatu fasilitas yang secara yuridis bank tidak mempunyai kewajiban untuk memenuhinya sesuai dengan yang telah diperjanjikan.

10) Jenis Pembiayaan Menurut Akad

Pembiayaan menurut akadnya dibagi atas pinjaman dengan akad pembiayaan dan pinjaman tanpa akad pembiayaan.

a. Pembiayaan dengan akad pembiayaan

Adalah pembiayaan yang disertai dengan suatu akad pembiayaan tertulis antara bank dan nasabah, antara lain mengatur besarnya plafond pembiayaan, suku bunga/nisbah, jangka waktu, jaminan, cara-cara pelunasan, dan sebagainya.

b. Pembiayaan tanpa akad pembiayaan

Adalah pembiayaan yang disertai suatu akad tertulis

11) Jenis pembiayaan two step loan, buyer's credit, on shore loan, dan offshore loan. a. Two Step Loan

Adalah suatu pembiayaan yang diperoleh dari lender (lembaga keuangan) diluar negeri.

b.Buyer's credit

Adalah suatu fasilitas yang diberikan kepada importir (buyers) yang disediakan oleh bank-bank diluar negeri untuk pembiayaan impor/pembelian barang (khususnya barang modal) yang berasal dari negara bank pemberi fasilitas luar negeri.

c. On shore loan

Adalah pemberian pembiayaan dalam valuta asing yang pada beberapa bank danaya dikelola divisi treasury.

d. offshore loan 
Adalah pemberian pembiayaan dalam valuta asing oleh kantor bank yang ada diluar negeri kepada customer-customer dalam negeri sehingga menimbulkan kewajiban membayar kembali terhadap luar negeri.

12) Jenis pembiayaan sindikasi

Adalah suatu pembiayaan bersama terhadap suatu objek pembiayaan oleh beberapa bank/lembaga pembiayaan, baik pembiayaan jangka pendek, menengah, maupun panjang di mana resiko pembiayaan ditanggung bersama oleh bank/lembaga pembiayaan pemberi pembiayaan.

13) Jenis pembiayaan konsorsium dan joint financing (musyarakah)

a. Konsorsium

Adalah fasilitas pembiayaan yang diberikan kepada customer yang pembiayaannya dilaksanakan secara bersama, biassanya antar sesama bank-bank pemerintah, meskipun tidak tertutup kemungkinan dengan bank swasta besar.

b.Joint financing (musyarakah)

Merupakan suatu cara pembiayaan yang dilaksanakan secara bersama-sama bank nasional dengan bank asing.

14) Jenis pembiayaan kelolaan

Adalah pembiayaan yang bersifat chanelling. Kemudian menunjuk suatu bank sebagai penatausaha pinjaman tersebut dan atas penantausahaan pinjaman ini bank memperoleh fee jasa perbankan.

15) Jenis pembiayaan Imfas, Usance $L / C$, dan SKBDN

Adalah Jenis pembiayaan ini berkenaan dengan impor.

3. Kualitas Pembiayaan

Pembiayaan bank menurut kualitasnya pada hakikatnya didasarkan atas kemungkinan menurut bank terhadap kondisi dan kepatuhan nasabah pembiayaan dalam memenuhi kewajiban-kewajiban untuk membayar bagi hasil, mengangsur, serta melunasi pembiayaan kepada bank. Jadi, unsur utama dalam menentukan kualitas tersebut oleh waktu pembayaran bagi hasil, pembayaran angsuran maupun pelunasan pokok pembiayaan dan perinci sebagai berikut :

1) Pembiayaan lancar adalah Pembayaran yang digolongkan lancar apabila memenuhi kriteria tersebut di bawah ini :

a. Pembayaran angsuran pokok dan /atau

b. Memiliki mutasi rekening yang aktif.

c. Bagian dari pembiayaan yang dijamin dengan agunan tunai

2) Perhatian khusus adalah Pembiayaan yang digolongkan kedalam pembiayaan dalam perhatian khusus apabila memenuhi kriteria sebagai berikut :

a. Terdapat tunggakan angsuran pokok

b. Kadang-kadang terjadi cerukan

c. Mutasi relatif aktif

d. Jarang terjadi pelanggaran terhadap kontrak yang diperjanjikan

e. Didukung oleh pinjaman baru.

3) Kurang lancar adalah Pembiayaan yang digolongkan kedalam pembiayaan kurang lancar apabila memenuhi kriteria berikut ini. 
a. Terdapat tunggakan angsuran pokok dan/atau bunga yang telah melampaui 90 hari

b. Sering terjadi cerukan

c. Frekuensi mutasi rekening relatif rendah

d. Terjadi pelanggaran terhadap kontrak yang diperjanjikan lebih dari 90 hari

e. Terdapat indikasi masalah keuangan yang dihadapi debitur

f. Dokumentasi pinjaman yang lemah

4) Diragukan adalah Pembiayaan yang digolongkan ke dalam pembiayaan diragukan apabila memenuhi kriteria sebagai berikut.

a. Terdapat tunggakan angsuran pokok

b. Terjadi cerukan yang bersifat permanen

c. Terjadi wanprestasi lebih dari 180 hari

d. Terjadi kapitalisasi bunga

e. Dokumentasi hukum yang lemah baik untuk perjanjian pembiayaan maupun pengikatan jaminan.

5) Macet adalah Pembiayaan yang digolongkan ke dalam pembiayaan macet apabila memenuhi kriteria berikut.

a. Terdapat tunggakan angsuran pokok

b. Kerugian operasional ditutup dengan pinjaman baru

c. Dari segi hukum maupun kondisi pasar, jaminan tidak dapat dicairkan pada nilai wajar. ${ }^{11}$

4. Tehnik penyelesaian pembiayaan bermasalah

Berikut ini adalah penyelesaian pembiayaan bermasalah :

a. Subrogasi : penyelesaian sebagian atau seluruh kewajiban debitur oleh kreditur baru.

b. Novasi : pengalihan kewajiban debitur oleh debitur lain dalam rangka pemanfaatan faktor-faktor produksi yang dimiliki debitur oleh debitur baru yang mengambil alih kewajiban dimaksud.

c. Kompensasi : penyelesaian sebagian atau seluruh kewajiban debitur dengan cara pengalihan hak atas aktiva tetap debitur kepada bank untuk dimanfaatkan sendiri atau dijual kembali.

d. Likuidasi dibawah tangan : penjualan sebagian atau seluruh agunan untuk menyelesaikan sebagian atau seluruh kewajiban debitur berdasarkan kesepakatan.

\section{METODE PENELITIAN}

Dalam penelitian dikenal dua pendekatan yaitu pertama pendekatan kualitatif dan kedua pendekatan kuantitatif. Dalam penelitian ini, peneliti menggunakan pendekatan pertama yaitu penelitian kualitatif. Menurut Bogdan dan Taylor metodologi kualitatif sebagai prosedur penelitian yang menghasilkan data deskriptif berupa kata-kata tertulis atau lisan dari orang-orang dan perilaku yang dapat diamati. Menurut mereka, pendekatan ini diarahkan pada latar dan individu tersebut secara bolistike (utuh). Jadi, dalam hal ini tidak

15 Veithzal Rivai, Islamic Banking (Jakarta: Sinar Grafika, 2010), hlm.715. 
boleh mengisolasikan individu atau organisasi ke dalam variabel atau hipotesis, tetapi perlu memandangnya sebagai bagian dari sesuatu keutuhan.

Sejalan dengan definisi tersebut, Kirk dan Miller mendefinisikan bahwa penelitian kualitatif adalah tradisi tertentu dalam ilmu pengetahuan sosial yang secara fundamental bergantung dari pengamatan pada manusia baik dalam kawasannya maupun dalam peristilahannya. $^{12}$

Oleh karenanya pada penelitian ini peneliti akan melakukan penelitian kualitatif secara deskriptif yang akan menghasilkan data deskriptif berupa kata-kata tertulis atau lisan dari orang-orang dan perilaku yang dapat diamati.

\section{PEMBAHASAN}

\section{JENIS $H A W A L A H$ APAKAH YANG DIPAKAI KJKS UGT BMT SIDOGIRI KCP OMBEN PADA PEMBIAYAAN BERMASALAH TAHUN BUKU 2018.}

Hawalah merupakan salah satu alat untuk mengurangi pembiayaan bermasalah di BMT Sidogiri. Yang dimaksud dengan hawalah adalah jasa pengalihan tanggung jawab pembayaran utang dari seseorang yang berutang kepada orang lain.

Dasar hukumnya adalah dari HR. Bukhari, bahwa: "menunda-nunda pembayaran uatang yang dilakukan oleh orang mampu adalah suatu kezaliman. Maka, jika seseorang diantara kamu dialihkan hak penagihan piutangnya (di-hawalab-kan) kepada pihak yang mampu, maka terimalah. ${ }^{13}$

Adapun rukun hawalah adalah mubil yakni orang yang berutang dan sekaligus berpiutang, mubal atau mubtal, yakni orang berpiutang kepada mubil, mubal alaih yakni orang yang berutang kepada mubil dan wajib membayar utang kepada mubtal, mubal bih yakni utang mubil kepada mubtal dan sighat (ijab-qabul. ${ }^{14}$

Syarat dilakukannya hawalah ada lima :

1. Mubil (orang yang berhutang kepada mubtal/orang yang mengalihkan hutangnya) dan mubtal (orang yang mempunyai piutang kepada mubil/orang yang menerima pengalihan hutang) sama sama rela atas pengalihan hutang.

2. Hutang yang ada pada mubil dan mubal alaib (orang yang mempunyai tanggungan hutang kepada mubil/orang yang hutangnya dialihkan kepada mubtal) sudah menjadi tanggungan yang tetap. Maka akad hawalah jika tidak timbul dari orang yang tidak punya hutang.

3. Dapat dijadikan 'iwad (alat tukar menukar) menurut syariat.

4. Hutang yang ada pada mubil dan mubal alaib diketahui kadar, sifat dan jenisnya.

5. Hutang yang menjadi tanggungan mubil dan mubal alaib harus sama. Jika tidak sama akad hawalah tersebut tidak sah.

Adapun rukun dan syarat sahnya hawalah yang ada di KJKS UGT BMT Sidogiri KCP Omben sudah sesuai dengan rukun dan syarat menurut ekonomi Islam dan fatwa DSN MUI tentang hawalah.

17 Lexy J.Moleong, Metodologi Penelitian Kualitatif (Bandung: PT Remaja Rosdakarya, 2008), hlm.4.

${ }^{13}$ Wirdyaningsih, Bank dan Asuransi Islam Di Indonesia (Kencana Prenada Media: Jakarta, 2005), hlm.132.

${ }^{14}$ Fatwa Dewan Syariah Nasional MUI. 
Rukun dan syarat dilakukannya hawalah Adapun rukun dan syarat melaksanakan biwalah harus memenuhi seperti ada pihak pertama sebagai mubil, kedua sebagai mubtal, ketiga sebagai mubal alaih, hutang pihak pertama ke pihak kedua, hutang pihak ke tiga ke pihak petama dan sighat. Adapun syaratnya harus cakap melakukan hukum, baligh, berakal, harus ada unsur kerelaan dari masing masing yang terlibat tanpa ada pemaksaan, hal yang dialihkan sudah dalam bentuk hutang pituang yang sudah pasti. kemudian persetujuan bahwa adanya pengalihan hutang.

\section{IMPLEMENTASI HAWALAH PEMBIAYAAN BERMASALAH STUDI DI KJKS UGT BMT SIDOGIRI KCP OMBEN}

Hawalah merupakan salah satu akad yang dipergunakan oleh bank syariah dalam kegiatan pelayanan jasa, disamping kafalah dan sharft. Bank syariah mempergunakan hawalah dalam dua kegiatan pelayanan jasa pemberian dan pengalihan hutang.

Sebagai sebuah transaksi di ranah pemberian jasa layanan, hawalah memberikan beberapa keuntungan, baik kepada bank maupun kepada nasabah. Ia berperan dan mempercepat penyelesaian utang piutang karena adanya dana talangan. Bagi bank syariah, ia merupakan sumber pendapatan non pembiayaan, sedangkan bagi nasabah, ia dapat membantu nasabah untuk mendapatkan instant cash sehingga dapat meningkat cash flow perusahaannya. Namun demikian, hawalah pun bukan tanpa resiko, terutama kemungkinan adanya kecurangan nasabah dengan memberikan invoice palsu atau ingkar janji (wanprestasi).

Adapun penerapan hawalah di KJKS UGT BMT Sidogiri KCP Omben yakni merujuk pada ekonomi syariah dan fatwa DSN MUI yang telah memutuskan terkait dengan hawalah. Pelaksanaan hawalah yakni antara mubil dan mubal alaih mendatangi KJKS UGT BMT Sidogiri KCP Omben untuk memberikan keterangan bahwa angsuran yang menjadi tanggungan pihak mubil akan dilanjutkan angsuran pembiayaannya oleh pihak mubal alaib ketika secara sah dibiwalabkan dengan memenuhi syarat dan rukunya.

Perincian sisa pembiayaan mubil akan diberikan secara tertulis oleh KJKS UGT BMT Sidogiri KCP Omben kepada pihak mubal alaih agar tidak terjadi kesalahfahaman, antara mubal alaib dan mubtal. Oleh karena perincian tersebut akan dijelaskan secara jelas dihadapan mubil dan mubal alaib hal itu karena merupakan sebuah syarat sah nya dalam melakukan bawalah. Sehingga jika perincian bisa diterima oleh pihak mubal alaih dan tidak ada unsur paksaan didalamnya kepada mubil dan mubal alaih maka bawalahpun bisa di ijab-qabulkan oleh yang bersangkutan hal ini KJKS UGT BMT Sidogiri KCP Omben dengan disertai surat persetujuan yang bermaterai.

Sedangkan persyaratan administrasi dibutuhkan jika mubal alaib menginginkan adanya perubahan atas nama pembiayaan yang awalnya atas nama mubil namun setelah secara sah dialihkan menjadi tanggungan mubal alaih, maka harus menyertai syarat dalam pengajuan pembiayaan sebagai berikut:

1. Mengajukan permohonan

2. Pemohon merupakan anggota BMT-UGT dengan minimal saldo 5 ribu rupiah

3. Mengisi formulir pembiayaan Murabahah

4. Foto copy KTP, bagi yang sudah berkeluarga KTP (Suami dan Istri)

5. Foto copy KK (Kartu Keluarga)

6. Foto copy Surat Nikah

7. Foto Copy Jaminan sebagai Pengikat. 
8. BMT mensurvey ketempat anggota

9. Menandatangani perjanjian pembiayaan murabahah

Persyaratan administrasi di atas tidak termasuk dalam peraturan hukum Islam dalam melakukan pembaiayaan murabahah, namun merupakan peraturan dari KJKS BMT Usaha Gabungan Terpadu Sidogiri KCP Omben dan hal ini tidak merugikan kedua belah pihak.

Dari ulasan di atas dapat diketahui letak ketidak cocokan yang kedua terletak pada syarat-syarat administrasi pembiayaan di BMT Sidogiri Omben tersebut. Dalam hal ini bukan berarti agama Islam melarang untuk melaksanakan pembiayaan di BMT Sidogiri, tapi dengan adanya syarat-syarat tersebut telah menjadikan sebagai aturan-aturan yang menjadi ketentuan dilembaga keuangan syariah tersebut, dengan tujuan agar anggota tidak melakukan, penipuan kelalaian, ataupun hal-hal yang melanggar perjanjian yang sudah disepakati bersama.

\section{PENUTUP}

1. BMT Sidogiri KCP Omben sebagai lembaga yang mengoperasikan produk hawalah bahwa penerapannya perlu lebih di sosialisasikan agar bisa mengurangi tingkat pembiayaan bermasalah.

2. Penelitian ini diharapkan bisa dijadikan sebagai informasi secara umum mengenai pengalihan hutang atau hawalah dan pembiayaan yang ada di BMT Sidogiri KCP Omben, sehingga bisa menumbuhkan kepercayaan dan minat nasabah atau anggota untuk menggunakan produk pembiayaan dari BMT Sidogiri KCP Omben.

\section{DAFTAR PUSTAKA}

Adiwarman Karim. Bank Islam Jakarta PT.Raja Grafindo.2010.

Heykal Muhammad .Huda Nurul. Lembaga Kenangan Islam Jakarta Kencana Prenda Media Group,2010.

Burhanuddin. Hukum Kontrak Syariah Yogyakarta BPFE Yogyakarta.

Nurhayanti Sri. Akuntansi Syariah Di Indonesia Jakarta Salemba Empat.2011.

Al Barry M.Dahlan. Kamus Modern Bahasa Indonesia Yogyakarta Arkola.1994.

Karim Adiwarman. Bank Islam Jakarta PT.Raja Grafindo.2011.

Solihin Ahmad Ifham. Ekonomi Syariah Jakarta PT. Gramedia Pustaka Utama.2010.

Solihin Ahmad Ifham. Pedoman Umum Lembaga Kenangan Syariah Jakarta PT.Gramedia.2010.

M.Ali.Hasan. Berbagai Macam Transaksi dalam Islam Jakarta PT.Raja Grafindo.2004.

Veithzal Rivai. Islamic Banking Jakarta Sinar Grafika.2010.

Kasmir. Dasar-dasar perbankan Jakarta PT Raja Grafindo.2002.

Lexy J.Moleong, Metodologi Penelitian Kualitatif Bandung PT Remaja Rosdakarya.2008. 
Buna'i. Metodologi Penelitian Pendidikan Pamekasan STAIN Pamekasan PRESS.2006.

Kasiram. Metodologi Penelitian Yogyakarta UIN Maliki Press.2010.

Hamidi. Metode Penelitian Kualitatif Malang UMM Press.2010.

Kasiram. Metodologi penelitian kuantitatif-kualitati Malang UIN-Malang Press.2008. 